\title{
A novel analytical liquid chromatography-tandem mass spectrometry method for the estimation of Ribavirin in bulk and pharmaceutical formulation
}

\author{
Prachi Sharma ${ }^{1}$, Narenderan S. $T^{1}$, Meyyanathan S. ${ }^{1 *}$, Sangamithra R ${ }^{1}$, Mohire Sourabh Sanjay ${ }^{1}$, Babu B ${ }^{1}$, Kalaivani M² \\ ${ }^{1}$ Department of Pharmaceutical Analysis, JSS College of Pharmacy, JSS Academy of Higher Education \& Research, Ooty, Nilgiris, Tamil Nadu, India. \\ ${ }^{2}$ Indian Pharmacopoeia Commission, New Delhi, India.
}

\begin{tabular}{l}
\hline ARTICLE INFO \\
\hline Received on: 26/09/2019 \\
Accepted on: 09/11/2019 \\
Available online: 03/01/2020 \\
\hline Key words: \\
Ribavirin, formulation, \\
LC-MS/MS, validation, ICH.
\end{tabular}

\section{INTRODUCTION}

Ribavirin that is also known as virazole is having the chemical formula of 1-[(2R, 3R, 4S, 5R)-3, 4-dihydroxy-5(hydroxymethyl) oxolan-2-yl]-1, 2, 4-triazole-3-carboxamide. The molecular formula of Ribavirin is $\mathrm{C}_{8} \mathrm{H}_{12} \mathrm{~N}_{4} \mathrm{O}_{5}$ with the molecular weight of $244.206 \mathrm{~g} / \mathrm{mol}$ (Drug information, 2018).

From the literature review, it was observed that there are some methods used for the estimation of Ribavirin in biological matrices, such as serum (Danso et al., 2011), human plasma (Ferreiros et al., 2014; Loregian et al., 2007), rat plasma, and brain (Shi et al., 2015; Zironi et al., 2011), but

\section{${ }^{*}$ Corresponding Author}

Dr. S.N. Meyyanathan, Professor, Department of Pharmaceutical Analysis, JSS College of Pharmacy, JSS Academy of Higher Education \& Research, Ooty, Nilgiris, Tamil Nadu, India.E-mail: snmeyyanthan@jssuni.edu.in no analytical method has been developed for the estimation of Ribavirin in its formulation. Furthermore, the reported methods on biological matrices were less sensitive to the quantification limit of more than $5 \mathrm{ng} / \mathrm{ml}$ and the run time of more than 5 minutes. Therefore, the aim of this present study was to develop a highly sensitive, simple, and economical method with less retention time for the estimation of Ribavirin drug than using the liquid chromatography-tandem mass spectrometry (LC-MS-MS) instrument.

\section{EXPERIMENTS}

\section{Materials}

The Ribavirin working standard was provided by the Indian Pharmacopeia Commission (IPC), New Delhi, India, as a gift sample. Ammonium formate that was purchased from Rankem Fine Chemical Ltd., LC-MS grade acetonitrile from Sigma Aldrich and water of LC-MS grade by Milli-Q Reverse osmosis (RO) System (Millipore, Bedford, MA, USA) were used. 


\section{Instrumentation and conditions}

The liquid chromatography system has been coupled with a tandem quadrupole mass spectrometer (Shimadzu 8030. Tokyo, Japan) having an LC-20AD pump, electrospray ionization interface, photodiode array (PDA) detector (SPD-M20), column oven (CTO-20AC),CEM-20Alite controller, and SIL-20AC autosampler. Lab solution data station software was used. Initially, different chromatographic conditions with different buffers were used. However, the use of acidic buffers (formic acid and acetic acid) affected the separation of the analyte. The use of ammonium acetate buffer gave a good separation of analyte, but the mass detection was less; after a number of trial and errors, the separation and quantification of Ribavirin separation (isocratic) was achieved by Zorbax $\mathrm{C}_{18}$ column $(4.6 \times 50 \mathrm{~mm}, 5 \mu \mathrm{m})$ as a stationary phase for rapid determination with ammonium formate ( $\mathrm{pH} 7.5)$ : acetonitrile at the ratio of $30: 70, \mathrm{v} / \mathrm{v}$ at a flow rate of 0.5 $\mathrm{ml} / \mathrm{min}$, and an injection volume of $10 \mu \mathrm{l}$.

\section{Selection of mass range}

The Ribavirin drug solution $(1,000 \mathrm{ng} / \mathrm{ml})$ was directly injected into the LC-MS/MS and scanned over the range of 150-350 to determine the precursor ion (see Fig. 1). Furthermore, the multiple reaction monitoring (MRM) chromatograms were obtained for transitions $244.90 \rightarrow 113.15(+)$ collision energy $(\mathrm{CE}):-11.0$ (quantification) and $244.90 \rightarrow 96.05(+) \mathrm{CE}:-31.0$ (detection), as shown in Fig. 2.

\section{Preparation of mobile phase}

For mobile phase preparation, $0.63 \mathrm{~g}$ of ammonium formate was dissolved in 1,000 $\mathrm{ml}$ of Millipore water and filtered through $0.45 \mu \mathrm{m}$ using a Millipore filtration unit.

\section{Preparation of Ribavirin standard stock and working solution}

Ribavirin (100 mg) standard was taken and transferred into a $100-\mathrm{ml}$ standard flask into which $50-\mathrm{ml}$ methanol (diluent) was added and dissolved. Furthermore, the content was made up to the volume using the diluent. From the stock solution, dilutions were made to prepare the linearity range solutions of $2,10,20,40,60,80$, and $100 \mathrm{ng} / \mathrm{ml}$. The quality control samples of low quality (LQC) $6 \mathrm{ng} / \mathrm{ml}$, sample of medium quality (MQC) $50 \mathrm{ng} / \mathrm{ml}$, and sample of high quality (HQC) $90 \mathrm{ng} / \mathrm{ml}$ were also prepared.

\section{Validation study}

As per ICH guidelines, parameters, such as specificity, accuracy, linearity, precision studies, detection limit (LOD), and quantitation limit (LOQ), were studied for the developed method (ICH, 2005).

\section{Specificity}

The excipients that interfere were determined by injecting standards into the system to determine the method specificity.

\section{Linearity}

Linear for Ribavirin was analyzed at six concentration levels ranging from 2 to $100 \mathrm{ng} / \mathrm{ml}$. The linearity graph was used to calculate the standard deviation and regression coefficient.

\section{Accuracy and precision}

Recovery studies performed to determine the method accuracy at three concentration levels (LQC, MQC, and HQC) at replicates for each concentration were evaluated. For determining the precision of the method, three different quality control (QC) concentrations were taken and analyzed on the same day and on different days and the results were represented as percentage relative standard deviation ( $\%$ RSD) for each concentration.

\section{$L O D$ and $L O Q$}

LOD and LOQ for Ribavirin were calculated by the signal-to-noise ratio. The signal-to-noise ratio of 3:1 was used to determine the LOD, and the 10:1 signal-to-noise ratio was used to determine the LOQ.

\section{Robustness}

The robustness of the method depends on the experimental conditions (operators, mobile phase used, and types of columns). The parameters, such as mobile phase (acetonitrile) concentration, buffer (ammonium formate) concentration, and flow rate, were studied for robustness.

System suitability

The system suitability is an important parameter for method development, and various factors were studied, such as tailing factor and linearity range.

\section{RESULTS AND DISCUSSIONS}

\section{Specificity}

The excipients that interfere were determined by injecting standards and elution of no peaks along with the retention time of Ribavirin. Therefore, the developed method signifies the selectiveness for Ribavirin determination in its formulation (see Fig. 2).

\section{Linearity}

The linearity curve was determined for the Ribavirin drug at six concentration levels ranging from 2 to $100 \mathrm{ng} / \mathrm{ml}$. The linearity curve shows a correlation coefficient of 0.9956 and with a regression equation of $y=949.63 x+2168.6$ (see Fig. 3 ).

\section{Accuracy and precision}

The standard addition method was used to determine the method accuracy at three QC levels. The percentage recovery of Ribavirin ranged from $94.00 \%$ to $98.33 \%$. The percentage RSD of intraday and interday precision results was found to be $0.67 \%-2.11 \%$ and $1.92 \%-3.11 \%$, respectively (see Table 1). Application of the method intended to study Ribavirin in a commercial tablet formulation.

\section{Determination of Ribavirin in its tablet formulation}

Twenty tablets were accurately weighed and powdered; $10 \mathrm{mg}$ powdered sample was transferred to a $10-\mathrm{ml}$ volumetric flask, 5-ml acetonitrile was added and kept in a sonicator, and then the volume was made up to $10 \mathrm{ml}$ using acetonitrile. After this, the resultant solution was shaken thoroughly and filtered through a syringe filter. The quality control samples of Ribavirin in different concentrations were prepared as follows: 6, 50, and $90 \mathrm{ng} / \mathrm{ml}$ (see Table 2 and Fig. 4). 

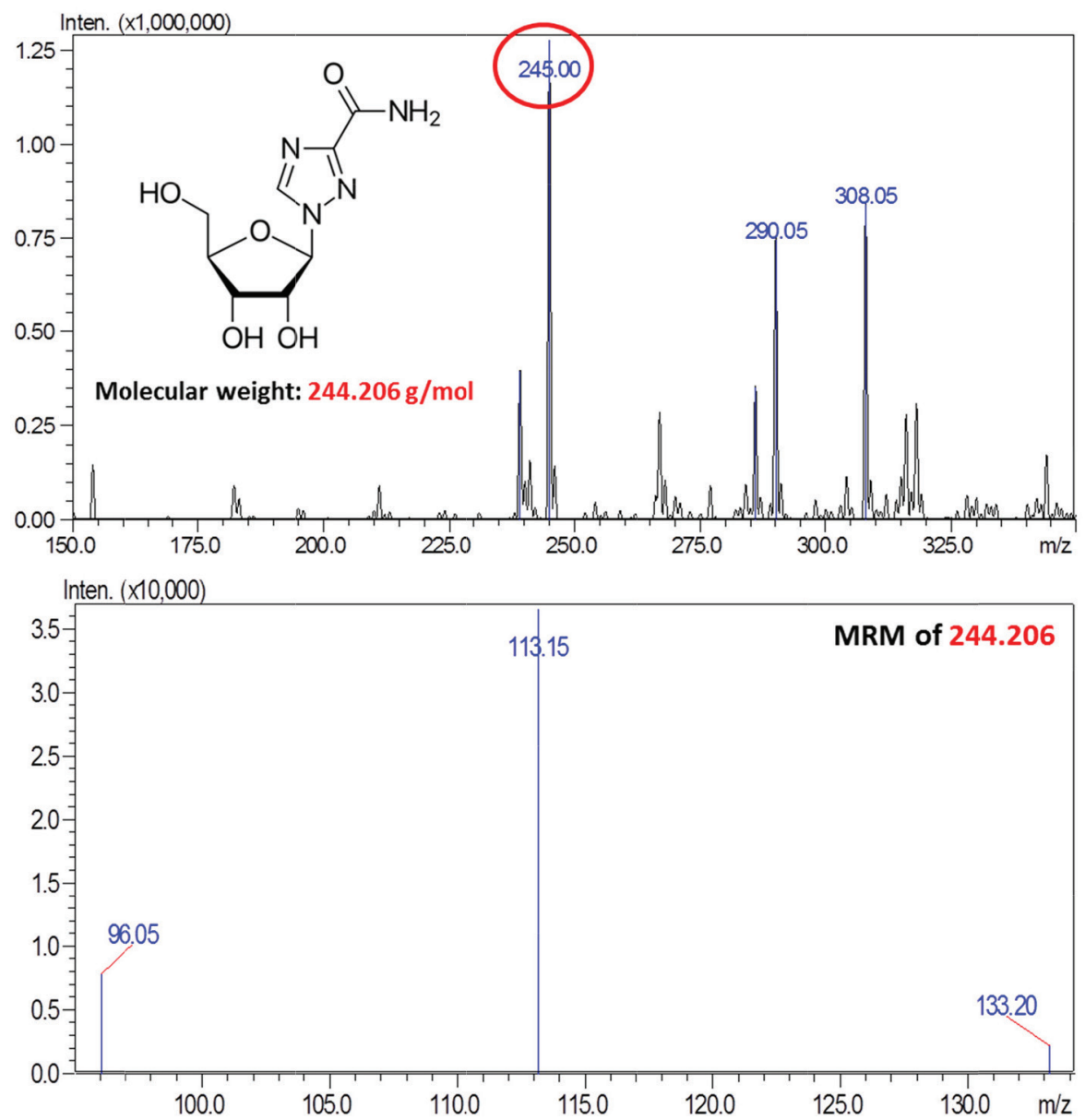

Figure 1. (a) Mass scan spectra and (b) MRM spectra for Ribavirin in positive mode.
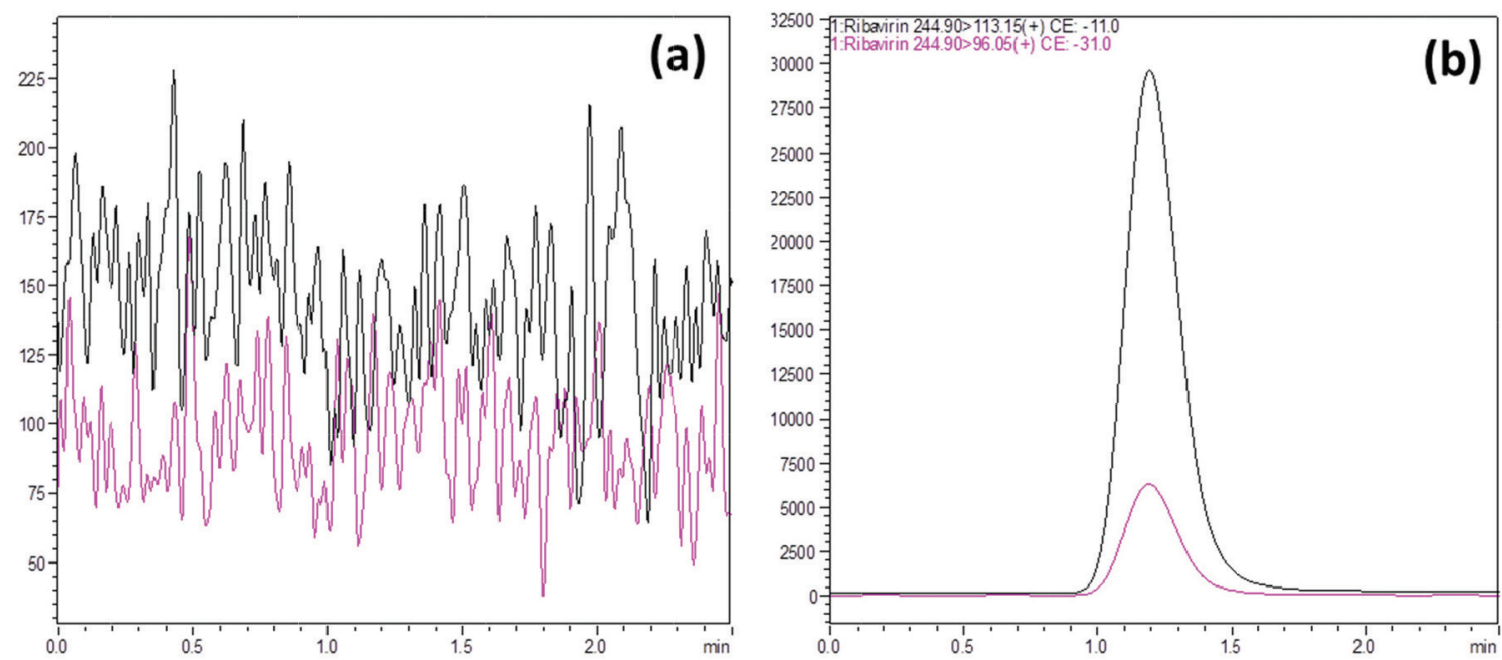

Figure 2. (a) Blank chromatogram of Ribavirin. (b) Standard chromatogram of Ribavirin.

\section{LOD and quantification limit (LOQ)}

LOD and LOQ for Ribavirin were calculated based on the signal-to-noise ratio. The LOD for Ribavirin was found to be $0.7 \mathrm{ng} / \mathrm{ml}$, and due to its low LOD, the quantification limit was $2 \mathrm{ng} / \mathrm{ml}$.

\section{Robustness}

The robustness of the method was determined by changing the operating conditions (operators, mobile phase used, and types of columns). The parameters, such as mobile phase concentration, were checked by changing the organic solvent 


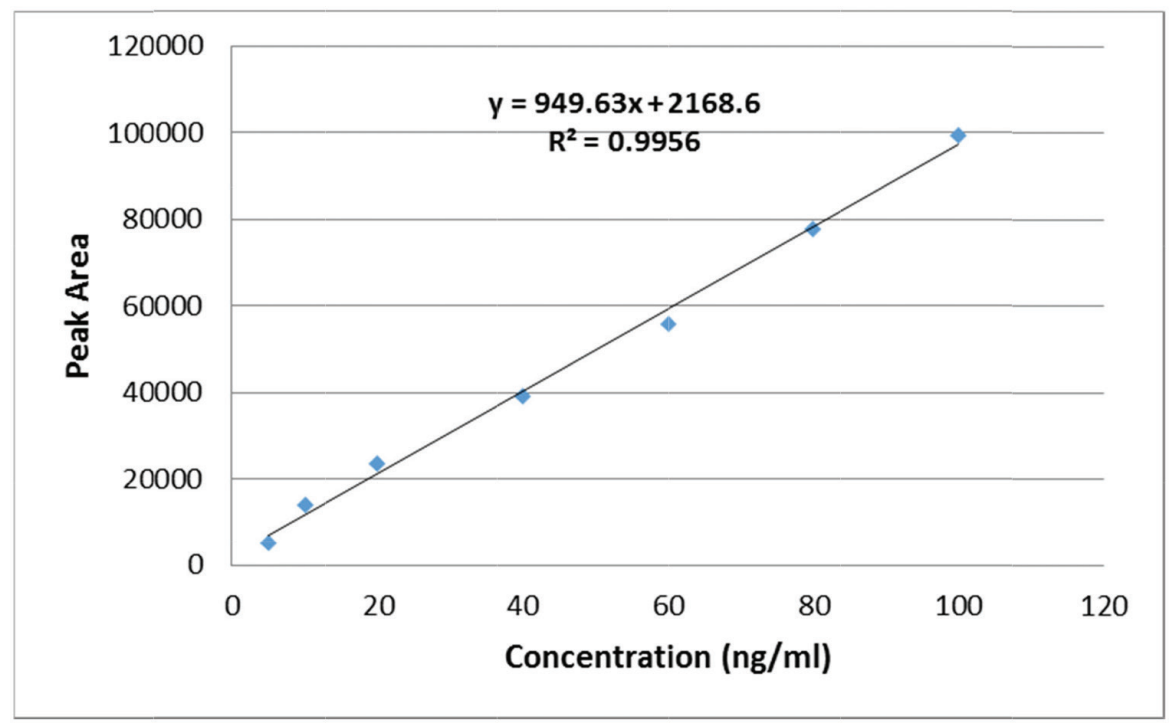

Figure 3. Linearity of Ribavirin.

Table 1. Accuracy and precision results of Ribavirin.

\begin{tabular}{cccccc}
\hline \multirow{2}{*}{$\begin{array}{c}\text { QC Samples } \\
(\mathbf{n g} / \mathbf{m l})\end{array}$} & $\begin{array}{c}\text { Mean Conc. } \\
\text { Found (ng/ml) }\end{array}$ & $\begin{array}{c}\text { Accuracy } \\
(\%)\end{array}$ & $\begin{array}{c}\text { Precision } \\
(\%) ~ R S D)\end{array}$ & $\begin{array}{c}\text { Accuracy } \\
(\%)\end{array}$ & $\begin{array}{c}\text { Precision } \\
(\% \text { RSD) }\end{array}$ \\
\hline 6 & $5.68 \pm 0.30$ & 94.66 & 2.11 & 92.34 & 3.11 \\
50 & $48.40 \pm 0.50$ & 96.88 & 1.03 & 94.44 & 2.70 \\
90 & $88.60 \pm 0.60$ & 98.44 & 0.67 & 96.27 & 1.92 \\
\hline
\end{tabular}

Table 2. Recovery results for Ribavirin in its formulation.

\begin{tabular}{lcccc}
\hline Formulation & Label Claim & $\begin{array}{c}\text { Assay level for QC } \\
\text { sample (ng/ml) }\end{array}$ & $\begin{array}{c}\text { Amount } \\
\text { Found (ng/ml) }\end{array}$ & \% Recovery \\
\hline \multirow{2}{*}{ Ribavirin* } & \multirow{2}{*}{$200 \mathrm{mg}$} & 6 & $5.64 \pm 0.05$ & 94.00 \\
& & 50 & $47.90 \pm 0.20$ & 95.80 \\
& 90 & $88.50 \pm 0.03$ & 98.33 \\
\hline
\end{tabular}

*Formulation $200 \mathrm{mg}$ Rebetol.

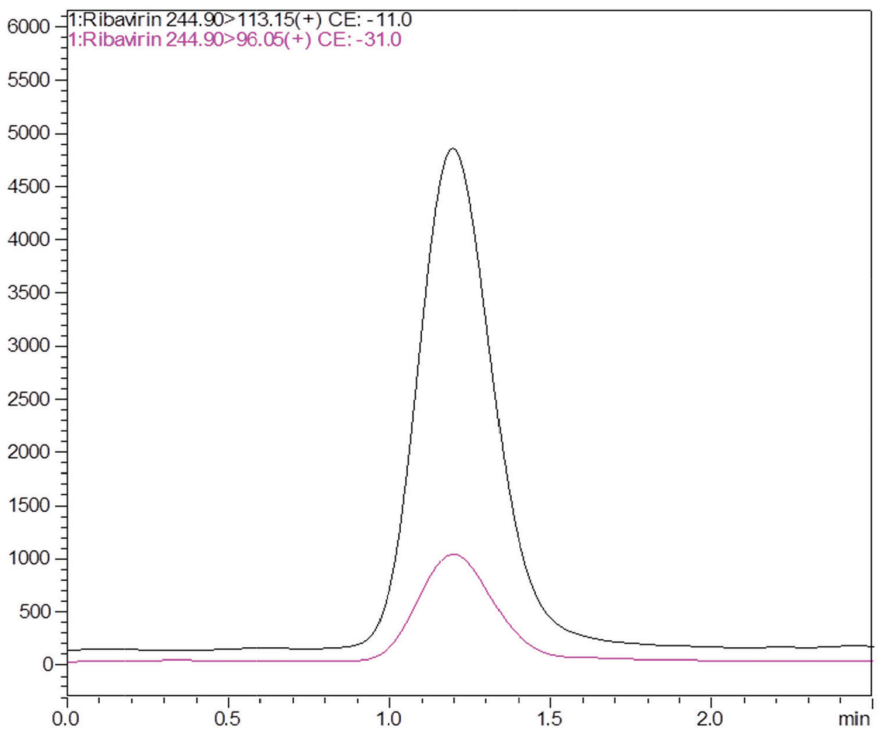

Figure 4. MRM chromatogram of Ribavirin in commercial formulation.
Table 3. System suitability parameter.

\begin{tabular}{clc}
\hline S.No & Parameters & Ribavirin \\
\hline 1 & Limit of detection & $0.7 \mathrm{ng} / \mathrm{ml}$ \\
2 & Limit of quantitation & $2 \mathrm{ng} / \mathrm{ml}$ \\
3 & Theoretical plates & 8,800 \\
4 & Tailing factors & 1.1 \\
5 & Linearity range & $2-100 \mathrm{ng} / \mathrm{ml}$ \\
6 & Correlation coefficient $\left(r^{2}\right)$ & 0.9956 \\
\hline
\end{tabular}

(acetonitrile) percentage $(60 \%, 70 \%$, and $80 \%)$ and buffer $\mathrm{pH}$ $(6.0,6.5$, and 7.0$)$ along with the mobile phase flow rate $(0.2,0.5$, and $0.7 \mathrm{ml}$ ). The results were represented in terms of RSD \%, and the obtained results were very much within the $3.0 \%$ limit.

\section{System suitability}

The system suitability of the method was determined against parameters such as tailing factor, linearity range, and validation parameters. The obtained results were found to be within the limit, indicating the suitability of the developed method (see Table 3 ).

\section{CONCLUSION}

The new method developed for the estimation of Ribavirin was found to be sensitive, simple, rapid, and economical with low retention time compared to the previously reported methods. The established method can be further used for the evaluation of Ribavirin in other marketed formulations. The values obtained from the analysis were found out to be within the acceptable limits as per the given ICH guidelines.

\section{ACKNOWLEDGMENT}

The authors are grateful to the Indian Pharmacopeia Commission (IPC), New Delhi, India, for providing Ribavirin as a gift sample.

\section{CONFLICT OF INTEREST}

All the authors declare that there are no conflicts of interest. 


\section{FINANCIAL SUPPORT AND SPONSORSHIP}

None.

\section{REFERENCES}

Danso D, Langman LJ, Snozek CL. LC-MS/MS quantitation of ribavirin in serum and identification of endogenous isobaric interferences. Clin Chim Acta, 2011; 412(23-24):2332-5.

Drug Information. (2018). [Online]. Available via https://www. drugbank.com (Assessed 10 June 2019).

Ferreiros N, Labocha S, El-Duweik J, Schlecker C, Lötsch J, Geisslinger G. Quantitation of ribavirin in human plasma and red blood cells using LC-MS/MS. J Sep Sci, 2014; 37(5):476-83.

ICH, Q2R1, validation of analytical procedures and methodology, 2005. [Online]. Available via https:/www.ich.org/products/guidelines/ quality/article/quality-guidelines.html (Accessed 15 July 2019).

Loregian A, Scarpa MC, Pagni S, Parisi SG, Palù G. Measurement of ribavirin and evaluation of its stability in human plasma by high-performance liquid chromatography with UV detection. J Chromatogr B, 2007; 856(1-2):358-64.
Shi X, Zhu D, Lou J, Zhu B, Hu AR, Gan D. Evaluation of a rapid method for the simultaneous quantification of ribavirin, sofosbuvir and its metabolite in rat plasma by UPLC-MS/MS. J Chromatogr B, 2015; 1002:353-7.

Zironi E, Gazzotti T, Lugoboni B, Barbarossa A, Scagliarini A, Pagliuca G. Development of a rapid LC-MS/MS method for ribavirin determination in rat brain. J Pharm Biomed Anal, 2011; 54(4):889-92.

How to cite this article:

Sharma P, Narenderan ST, Meyyanathan SN, Sangamithra R, Sanjay MS, Babu B, Kalaivani M. A novel analytical liquid chromatography tandem mass spectrometry method for the estimation of Ribavirin in bulk and pharmaceutical formulation. J Appl Pharm Sci, 2020; 10(1):096-100. 